\title{
Silicon improves the photosynthetic performance of black pepper plants inoculated with Fusarium solani f. sp. piperis
}

\author{
V. D'ADDAZIO*,+, J.V.G. SILVA*, A.S. JARDIM*, L.L. LONGUE*, R.A.A. SANTOS*, \\ A.A. FERNANDES ${ }^{*}$, M.B. SILVA*, D.M. SILVA**, T.A. SANTOS**, E.R. SCHMILDT*, \\ L.H. PFENNING***, and A.R. FALQUETO*,+
}

\author{
Federal University of Espírito Santo, Department of Agrarian and Biological Sciences, Rodovia Governador \\ Mario Covas, Km 60, 29932-540 Litorâneo, São Mateus, ES, Brazil ${ }^{*}$ \\ Federal University of Espírito Santo, Department of Biological Sciences, Avenida Fernando Ferrari, \\ 514 - 29075-910, Vitória, ES, Brazil ${ }^{* *}$ \\ Federal University of Lavras, Department of Phytopathology, University Campus, P. O. Box 3037 - 37200-000, \\ Lavras, $M G$, Brazil***
}

\begin{abstract}
This study evaluated the effect of silicon (Si)-supplementation in controlling the fusariosis in two Piper nigrum cultivars (Bragantina and Kottanadan). We hypothesized that susceptible cultivar improves the photosynthetic performance with Si-supplementation. Under greenhouse conditions, six-month-old plants were treated with silicon 30 and $15 \mathrm{~d}$ before inoculation with Fusarium solani f. sp. piperis and compared with untreated plants and with healthy control plants. All samples remained photosynthetically active after infection. Chlorophyll content, chlorophyll $a$ fluorescence, and leaf gas-exchange parameters were less affected in Si-supplemented plants as well as healthy control plants. The net carbon assimilation, stomatal conductance, associated with higher internal carbon values suggest that the lower $\mathrm{CO}_{2}$ influx in inoculated plants of Bragantina cultivar was caused by photochemical and biochemical limitations. Si-supplementation reduced the disease severity improving protection, apparently associated with the preservation of photosynthetic performance, especially for Bragantina cultivar.
\end{abstract}

Additional key words: photosynthesis; photosystem; plant defense; plant disease; plant nutrition; resistance responses.

\section{Introduction}

Root rot or fusariosis, caused by Fusarium solani f. sp. piperis, is the main disease for black pepper. This disease is restricted to Brazil (Tremacoldi 2010) reducing the reproductive cycle from 12 to 5-6 years (Lemos et al. 2011). The high yield losses caused by F. solani in black pepper, combined with the absence of efficient fungicides and resistant pepper cultivars (Tremacoldi 2010), makes F. solani one of the most important pathogens affecting black pepper yield in Brazil.
In the last years, many authors have demonstrated that silicon induces protection against several pathogens, as previously described for rice plants (Oryza sativa L.) infected by Bipolaris oryzae (Dallagnol et al. 2013), in soybean (Glycine max L.) infected by Diaporthe phaseolorum f. sp. meridionalis, which causes the stem canker (Debona et al. 2017), and in soybean infected by Phakopsora pachyrhizi and Phytophthora sojae, which cause the Asian soybean rust and root rot, respectively (Rasoolizadeh et al. 2018).

Overall, it appears that the Si influences the metabolic,

\footnotetext{
Received 24 September 2019, accepted 31 December 2019.

+Corresponding author; phone: +55 273312 1683, e-mail: antelmo.falqueto@ufes.br, veronicadaddazio@yahoo.com

Abbreviations: ABS/RC - absorption flux per reaction center of PSII; AUDPC - area under the curve of disease progress; BRA Bragantina; $C_{\mathrm{a}}$ - ambient $\mathrm{CO}_{2}$ concentration; $\mathrm{CE}$ - carboxylation efficiency; Chl - chlorophyll; $\mathrm{Chl}_{\text {total }}$ - total chlorophyll index; $C_{\mathrm{i}}$ - internal $\mathrm{CO}_{2}$ concentration; $C_{\mathrm{i}} / C_{\mathrm{a}}-$ intra/extracellular $\mathrm{CO}_{2}$ concentration; DAI - day after inoculation; $\mathrm{DI} / \mathrm{RC}-$ dissipated energy flux per reaction center of PSII; $E$ - transpiration rate; $\mathrm{F}_{0}$ - initial fluorescence; $\mathrm{F}_{\mathrm{m}}$ - maximum fluorescence; $\mathrm{F}_{\mathrm{v}} / \mathrm{F}_{\mathrm{m}}-\mathrm{maximum}_{\mathrm{m}}$ photochemical quantum yield of PSII; $g_{s}$ - stomatal conductance; KOT - Kottanadan; OEC - oxygen-evolving complex; OJIP transient - fluorescence induction transient defined by the names of its intermediate steps; $\mathrm{P}_{700}$ - the primary electron donor of photosystems; $\mathrm{PC}$ - plastocyanin; $\mathrm{PI}_{\text {total }}$ - photosynthetic performance index; $P_{\mathrm{N}}-$ net $\mathrm{CO}_{2}$ assimilation rate; $\mathrm{PQ}$ - plastoquinone; $\mathrm{Q}_{\mathrm{A}}$ and $\mathrm{Q}_{\mathrm{B}}-$ primary and secondary quinone electron acceptors of photosystem II, respectively; $\mathrm{RC}$ - reaction center; $\mathrm{Si}$ - silicon; $\mathrm{V}_{\mathrm{J}}-$ relative variable Chl $a$ fluorescence at the J-step; WUE - water-use efficiency; $\mathrm{WUE}_{\mathrm{i}}$ - intrinsic water-use efficiency; $\varphi_{\mathrm{D} 0}$ - quantum yield $($ at $\mathrm{t}=0)$ of energy dissipation; $\varphi_{\mathrm{E} 0}-$ quantum yield for electron transport $(\mathrm{ET}) ; \varphi_{\mathrm{R} 0}$ - quantum yield for reduction of the end electron acceptors at the PSI acceptor side; $\psi_{\mathrm{E} 0}$ - efficiency with which a trapped exciton can move an electron into the electron transport chain.

Acknowledgments: We thank the Coordination for the Improvement of Higher Education Personnel (CAPES) for fellowships. Dr. V. D'Addazio was supported by the Postgraduate Program from CAPES. This study was financed by Research Innovation Support Foundation of Espírito Santo (Edital FAPES no. 11 PPE - Agricultural Research in the Espírito Santo State).
} 
physiological, and/or structural activity of higher plants infected by pathogens (Fauteux et al. 2005, Datnoff et al. 2007, Meharg and Meharg 2015, Rodrigues et al. 2015). Physiologically, changes in the membrane permeability, degradation of cell membranes and photosynthetic pigments, protein synthesis, water potential, and absorption of nutrients and water occur, causing plant wilting and death (Wheeler and Rush 2001). Water relations of diseased plants can be affected by disturbances in stomatal functioning, increased resistance to flow and root water uptake, increasing the sensibility of host plants to water deficiency (Syvertsen et al. 1980). In addition, pathogen infection usually leads to the development of chlorotic and necrotic areas and a decreased photoassimilate production (Schreiber 2004), resulting from reduced leaf gas exchange and low performance of photochemical reactions associated to PSII (Berger et al. 2007). Also, the protection conferred to plants by $\mathrm{Si}$ might be related to its accumulation and polymerization in the cells, forming a mechanical barrier that hampers the development and growth of pathogens (Datnoff et al. 2007). However, mechanical barriers are not the only defense mechanism against pathogens stimulated by Si. Also, the accumulation of soluble phenolic compounds, lignin, phytoalexins, and other antimicrobial compounds in response to Si has been reported (Rodrigues et al. 2005, Fortunato et al. 2012). Cucumber (Cucumis sativus L.) plants inoculated with Pythium ultimum showed increased chitinase activity (Chérif et al. 1991). Moreover, Fawe et al. (1998) demonstrated that cells attacked either by P. ultimum or Sphaerotheca fuliginea accumulated phenolic material toxic to fungal structures, similar to the action described for phytoalexins.

Thus, as previously reported by Aucique-Pérez et al. (2014) and Rios et al. (2014), treatment with Si improves the net photosynthesis, increases the chlorophyll (Chl) content and improves the performance of photochemical reactions associated with PSII, which can be evaluated using in vivo Chl $a$ fluorescence (OJIP transient and JIPtest), reducing the intensities of several diseases (damping off, leaf blights, leaf spots, galls, powdery mildews, root rots, rusts, and wilts) caused by different genera of bacteria, fungi, nematodes, and oomycetes as well as viruses in many economically important crops (Fortunato et al. 2012, Rodrigues et al. 2015). Also, silicon has unique biochemical properties that may explain its bioactivity as a regulator of plant defense mechanisms, in addition to acting as a modulator influencing the timing and extent of plant defense responses in a manner reminiscent of the role of secondary messengers in induced systemic resistance (Fauteux et al. 2005). In rice plants (Oryza sativa L.) infected by Pyricularia oryzae, the Si-supplementation improved protection of the photosynthetic apparatus against chronic photoinhibition and indirectly protected the photosystems against photodamages, which frequently result in a state of chronic hyperexcitation (Domiciano et al. 2015). In the literature, few studies report the use of OJIP transients and the JIP-test to quantify changes in photochemical activity caused by fungal diseases or their pathogens (Ajigboye et al. 2016).
The present study aimed to evaluate the photosynthetic performance of black pepper plants, cv. Bragantina (susceptible) and Kottanadan (resistant), in the Piper nigrum $\times$ Fusarium solani f. sp. piperis pathosystem, in order to evaluate the effect of Si-supplementation in controlling the fusariosis. We hypothesized that the black pepper plants susceptible to fusariosis improve the photosynthetic performance with Si-supplementation.

\section{Materials and methods}

Plant material and cultivation: Four-month-old plants of black pepper cv. Kottanadan (KOT) and Bragantina (BRA) were planted in 5-L plastic pots (one plant per pot) containing $5 \mathrm{~kg}$ of sterilized soil [Haplic Planosol, sandy clay loam, previously solarized according to Ghini (2004)] and maintained in greenhouse conditions under approximately $800-1,000 \mu \mathrm{mol}\left(\right.$ photon) $\mathrm{m}^{-2} \mathrm{~s}^{-1}$, air temperature and relative humidity ranging from $24-30^{\circ} \mathrm{C}$ and $70-80 \%$, respectively. Previously, chemical analysis of soil was performed to correct nutrient and $\mathrm{pH}$ levels.

Plants were fertilized every $2 \mathrm{~d}$ with $100 \mathrm{~mL}$ of a modified nutrient solution (Fernandes et al. 2002) for six months until the onset of treatment. Then, plants were supplemented with $1.0 \mathrm{~g}$ (calcium silicate) $\mathrm{kg}^{-1}$ (soil) (Aldrich Chemistry $\left.{ }^{\circledR}\right) 30$ and 15 d before inoculation (ISi+) and compared with nonsupplemented plants (Isi-) and with healthy control plants (NISi-). The calcium silicate contained $62 \% \mathrm{SiO}_{2}$ and $18 \% \mathrm{CaO}$. All sampling and measurements were conducted using completely expanded third or fourth leaf from the apex, $180 \mathrm{~d}$ after inoculation (DAI), except the gas-exchange measurements, which were performed on 150 DAI. Ten measurements were made per treatment. After the application of silicon, the plants were fertilized every $3 \mathrm{~d}$ with $50 \mathrm{ml}$ of nutrient solution until the end of the experiment.

Inoculum production, spore suspension and inoculation procedure: Fusarium solani f. sp. piperis CML 2466, obtained from the Lavras Mycological Collection of Federal University of Lavras, Minas Gerais, was maintained in Petri dishes containing PDA (potato dextrose agar) medium at $4^{\circ} \mathrm{C}$. For inoculation, 5-mm discs from the culture were transferred to Petri dishes containing the same medium. The plates were incubated at $25^{\circ} \mathrm{C}$ in a biochemical oxygen demand (BOD) chamber, with 12-h photoperiod for $15 \mathrm{~d}$. The spore suspension was prepared by the addition of $20 \mathrm{ml}$ of sterile distilled water to each plate. The spore count was performed in a Neubauer chamber and the suspension was adjusted to a concentration of $10^{8}$ spores per $\mathrm{ml}$. To each vessel, $10 \mathrm{ml}$ of the spore suspension was added. The Koch postulates were observed.

Area under the curve of disease progress (AUDPC): The AUDPC was calculated according to Campbell and Madden (1990).

Chl $\boldsymbol{a}$ fluorescence and total $\mathrm{Chl}$ index: The Chl $a$ fluorescence induction kinetics was measured at room 
temperature using a plant efficiency analyzer (HandyPEA, Hansatech, King's Lynn, Norfolk, UK). Before the measurements, the leaves were dark-adapted for $30 \mathrm{~min}$ using a leaf clip (Hansatech). Light intensity reaching the leaf was 3,000 $\mu \mathrm{mol}$ (photon) $\mathrm{m}^{-2} \mathrm{~s}^{-1}$, which was sufficient to generate maximal fluorescence for all the treatments. The fast fluorescence kinetics $\left(\mathrm{F}_{0}\right.$ to $\left.\mathrm{F}_{\mathrm{m}}\right)$ were recorded from $10 \mathrm{~ms}$ to $1 \mathrm{~s}$ with 120 fluorescence points. The fluorescence intensity at $50 \mu \mathrm{s}$ (considered as $\mathrm{F}_{0}$ ), $100 \mu \mathrm{s}$, $300 \mu \mathrm{s}, 2 \mathrm{~ms}\left(\mathrm{~F}_{\mathrm{J}}\right), 30 \mathrm{~ms}\left(\mathrm{~F}_{\mathrm{I}}\right)$, and maximum fluorescence or $\mathrm{F}_{\mathrm{m}}$ were collected and used to obtain the parameters for the JIP-test (Strasser and Strasser 1995). The total Chl index $\left(\mathrm{Chl}_{\text {total }}\right)$ content was obtained using a ClorofiLOG model CFL 1030 chlorophyll meter.

Leaf gas-exchange variables: The net photosynthetic rate $\left(P_{\mathrm{N}}\right)$, stomatal conductance $\left(g_{\mathrm{s}}\right)$, transpiration rate $(E)$, and intercellular $\mathrm{CO}_{2}$ concentration $\left(C_{\mathrm{i}}\right)$ were estimated from 7 to $11 \mathrm{~h}$ (solar time) using a portable open-system infrared gas analyzer (LCpro-SD, ADC BioScientific) under an external $\mathrm{CO}_{2}$ concentration of $400 \mu \mathrm{mol} \mathrm{mol}^{-1}$ (air). All the measurements were conducted under artificial saturating photon irradiance $\left[1,000 \mu \mathrm{mol}\right.$ (photon) $\left.\mathrm{m}^{-2} \mathrm{~s}^{-1}\right]$. The intrinsic water-use efficiency $\left[\mathrm{WUE}_{\mathrm{i}}=P_{\mathrm{N}} / g_{\mathrm{s}}, \mu \mathrm{mol}\left(\mathrm{CO}_{2}\right)\right.$ $\left.\mathrm{mmol}^{-1}\left(\mathrm{H}_{2} \mathrm{O}\right)\right]$, water-use efficiency $\left[\mathrm{WUE}=P_{\mathrm{N}} / E\right.$, $\left.\mu \mathrm{mol}\left(\mathrm{CO}_{2}\right) \mathrm{mol}^{-1}\left(\mathrm{H}_{2} \mathrm{O}\right)\right]$, carboxylation efficiency $(\mathrm{CE}=$ $\left.P_{\mathrm{N}} / C_{\mathrm{i}}, \mu \mathrm{mol} \mathrm{mmol} \mathrm{mm}^{-1} \mathrm{ppm}^{-1}\right)$ and ratio between intra/extracellular $\mathrm{CO}_{2}$ concentrations $\left(C_{\mathrm{i}} / C_{\mathrm{a}}\right)$ were calculated.

Experimental design and data analysis: The experiment was performed using a randomized block design with plants noninoculated and inoculated with Fusarium solani f. sp. piperis treated and nonsupplemented with silicon (ISi+, Isi-, and NISi-). Each replication consisted of one plastic pot with one plant. The significance of treatment effects on all variables analyzed was tested with analysis of variance $(A N O V A)$ and the mean treatment values for each cultivar were compared by the $S$ cott-Knott's test $(p<0.05)$ using the software Genes 3.1 (Cruz 2016). The Pearson's linear correlation technique was used to determine the relationships among the photosynthetic traits and AUDPC (see Table 1).

\section{Results}

Area under the curve of disease progress (AUDPC): The Si-supplementation reduced the area under the curve of disease progress in both pepper cultivars infected by Fusarium (ISi+). However, AUDCP values were lower in Kottanadan than that in Bragantina $(-58 \%$ and $-33 \%$, respectively) (Fig. 1).

Chl $\boldsymbol{a}$ fluorescence and total $\mathbf{C h l}$ index: Noninoculated (NISi-) and inoculated plants with and without Si-supplementation (ISi+ and Isi-, respectively) showed OJIP curves with typical polyphasic behavior, with well-defined $\mathrm{J}$ and I intermediate steps (Fig. 2). For Kottanadan pepper cultivar, no change was observed at $\mathrm{J}$, I, and $\mathrm{P}$ steps in all treatments (Fig. 2A). In contrast, Si-supplementation resulted in increased $\mathrm{J}$, I, and $\mathrm{P}$ steps in Bragantina pepper cultivar, which was similar to NISi- (Fig. 2B). There was a significant difference for $\mathrm{F}_{0}, \mathrm{~F}_{\mathrm{m}}, \mathrm{F}_{\mathrm{v}} / \mathrm{F}_{\mathrm{m}}, \mathrm{V}_{\mathrm{J}}, \mathrm{DI}_{0} / \mathrm{RC}$, $\varphi_{\mathrm{E} 0}, \varphi_{\mathrm{R} 0}, \mathrm{PI}_{\text {total }}, \mathrm{Chl}_{\text {total }}, \mathrm{ABS} / \mathrm{RC}$, and $\varphi_{\mathrm{D} 0}\left(\right.$ Table 2). $\mathrm{F}_{0}$, $\mathrm{ABS} / \mathrm{RC}, \mathrm{DI}_{0} / \mathrm{RC}$, and $\varphi_{\mathrm{D} 0}$ values were higher in BRA independently of treatment (Table 2). The $\mathrm{Si}+$ increased $\mathrm{F}_{\mathrm{m}}, \varphi_{\mathrm{E} 0}$, and $\psi_{\mathrm{E} 0}$ values in inoculated Bragantina plants. $\varphi_{\mathrm{R} 0}$ values increased in Kottanadan plants inoculated and $\mathrm{Si}$-supplemented (ISi+), which was similar to NISi-. Also, Si-supplementation resulted in changes of $\mathrm{PI}_{\text {total }}$. For Kottanadan and Bragantina pepper cultivars, there were increases of $\mathrm{PI}_{\text {total }}$ values by approximately 49.8 and $34.2 \%$, respectively. Increases of $\approx 24$ and $11.7 \%$ in $\mathrm{Chl}_{\text {total }}$ occurred in Kottanadan and Bragantina cultivars, respectively, after $\mathrm{Si}$-supplementation (ISi+) compared to ISi- (Table 2).

Leaf gas-exchange variables: The results of the present study show that photosynthesis was impaired by inoculation in those plants nonsupplemented with $\mathrm{Si}$ (ISi-). However, $P_{\mathrm{N}}, g_{\mathrm{s}}$, WUE, WUE,$E$, and CE values increased in ISi+ for both pepper cultivars, compared with the corresponding control, ISi- and NISi- (Fig. 3A,B,D-G). Si-supplementation reduced $C_{\mathrm{i}}$ in Bragantina pepper cultivar and increased $C_{\mathrm{i}} / C_{\mathrm{a}}$ (Fig. $\left.3 B, H\right)$.

\section{Discussion}

The use of $\mathrm{Si}$ for resistance against plant diseases has been studied for several decades and several researchers have reported that $\mathrm{Si}$ can increase the resistance of plants against pathogenic fungi (Chérif et al. 1994, Fauteux et al. 2005, Datnoff et al. 2007, Resende et al. 2012, Debona et al. 2014, Tatagiba et al. 2016). In this study, in order to evaluate the efficiency of Si for the control of fusariosis caused by F. solani f. sp. piperis, a detailed photosynthetic analysis was carried out, comparing two black pepper cultivars, Kottanadan and Bragantina. Overall, pepper plants with $\mathrm{Si}+$ showed improved photosynthetic capacity and lower disease progress. To the best of our knowledge, this study is the first to evaluate the efficiency of Si for the control of fusariosis in black pepper infected by $F$. solani f. sp. piperis based on photosynthetic traits.

It was observed that soil $\mathrm{Si}$-supplementation $(\mathrm{Si}+)$ influenced the incidence of disease in both pepper cultivars, with reduction of AUDCP values for Kottanadan $(\approx 58 \%)$ and for Bragantina $(\approx 33 \%)$ infected by Fusarium compared with the ISi- plants (Fig. 1). These results allow us to attribute higher resistance to the Kottanadan compared with ISi- and NISi- plants, as well as increased resistance in Bragantina, which is considered by farmers susceptible to the presence of the fungus. Differences in the incubation period reflect differences in the pathogen growth rate in the host plants and, consequently, in the epidemic progress rate, being an important component of resistance (Spósito et al. 2004). In this context, it was observed that cv. Kottanadan had longer incubation periods than that of Bragantina, indicating higher resistance when evaluated by this parameter. In this study, these results are supported by negative correlation between incubation period and AUDCP values $(r=-0.8747, p=0.0013)$. According to 


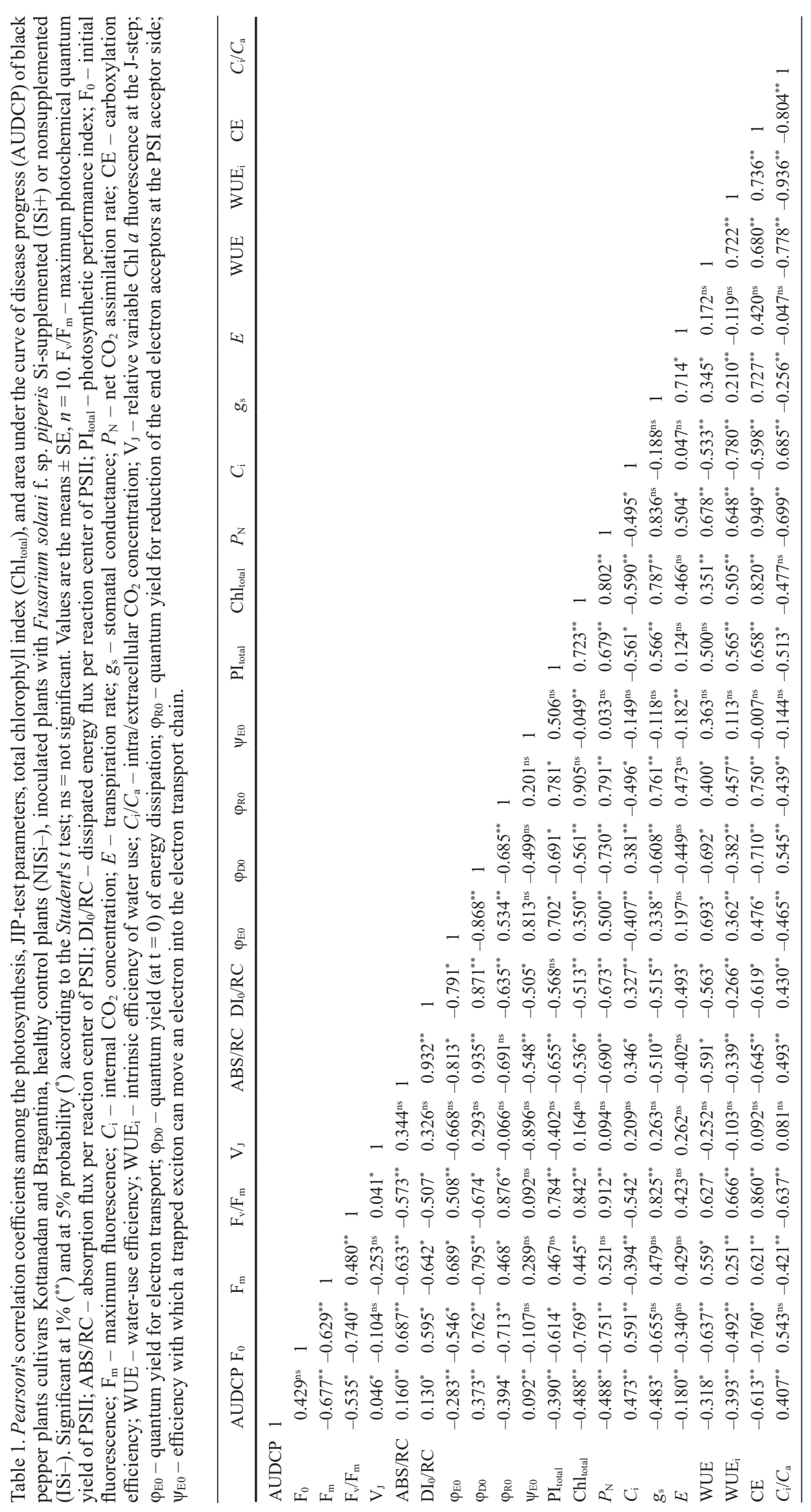




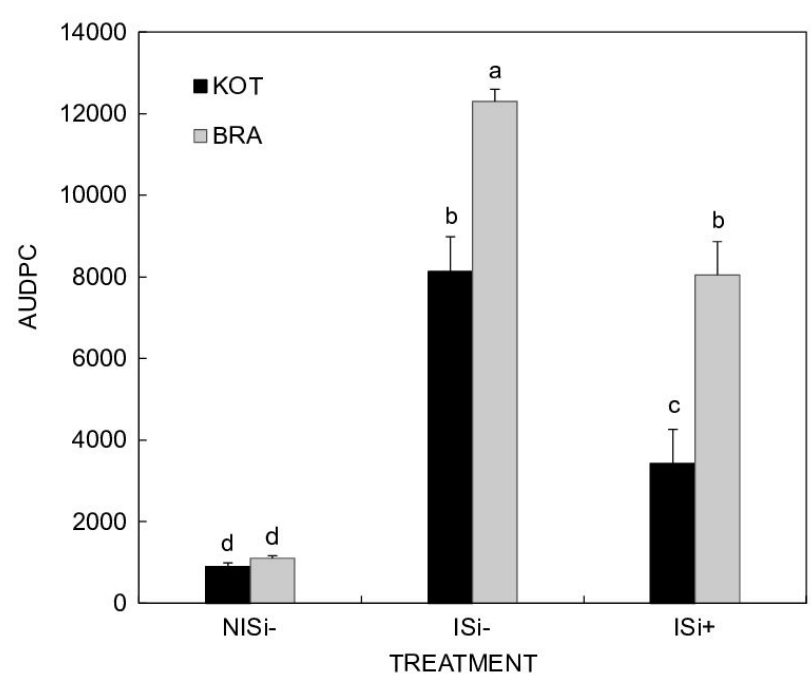

Fig. 1. Area under the curve of disease progress (AUDPC). evaluated at $180 \mathrm{~d}$ after inoculation, in two black pepper cultivars (KOT - Kottanadan and BRA - Bragantina), in healthy control plants (NISi-), Si-supplemented ( $\mathrm{ISi}+)$ or nonsupplemented (ISi-). All plants were inoculated with Fusarium solani f. sp. piperis except the control. Values are the means $\pm \mathrm{SE}, n=10$. Columns followed by the identical letter are not statistically different according to the Scott-Knott's test at $1 \%$ probability $(p<0.01)$.

Chérif et al. (1994), two hypotheses for the Si-enhanced resistance to diseases and pests have been proposed. One is that $\mathrm{Si}$ deposited on the tissue surface forms physical and biochemical barriers, which, consequently, reduces the effects of pathogens (Bélanger et al. 2003). It prevents physical penetration and/or makes the plant cells less susceptible to enzymatic degradation by fungal pathogens. This mechanism is supported by the positive correlation between the Si content and the degree of suppression of diseases and pests (Ratnayake et al. 2016). The other one is that $\mathrm{Si}$ functions as a signal to induce the production of phytoalexin. According to Berhow and Vaughn (1999), phytoalexins are produced by plants in response to invasion or contact with pathogenic microorganisms. Phytoalexins may be flavones, flavonoids, and isoflavonoids that inhibit the growth of various fungal species. The impact of $\mathrm{Si}$ on host resistance components can partially explain why the resistance of susceptible cultivars can be increased (Resende et al. 2013). These positive effects of Si have traditionally been associated with its role in alleviating abiotic and biotic stresses in addition to improving resistance to lodging and increasing the erectness of leaves, which allows better light transmittance through rice canopies and thereby potentially enhances whole-plant photosynthesis (Tamai and Ma 2008).

For both pepper cultivars, the OJIP transients showed a typical polyphasic behavior with the fluorescence signal rising from the initial fluorescence level $\left(\mathrm{F}_{0}\right)$ to the maximum level $\left(\mathrm{F}_{\mathrm{m}}\right)$ with well-defined intermediate $\mathrm{J}$ and I step. These results demonstrate that all samples were photosynthetically active after infection by Fusarium (Fig. 2). The relative stability of OJIP curves observed in

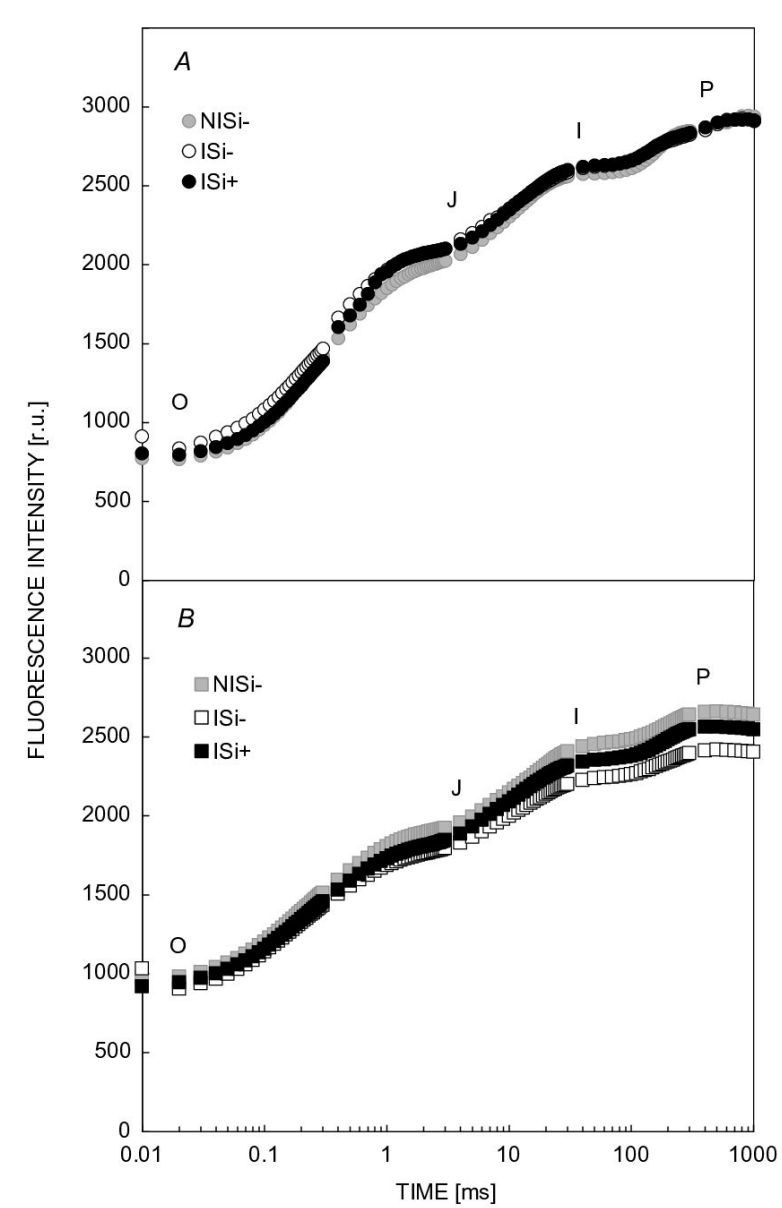

Fig. 2. Chlorophyll $a$ fluorescence transient curve (OJIP) in Kottanadan (KOT) $(A)$ and Bragantina (BRA) $(B)$ cultivars, healthy control plants (NISi-), inoculated with Fusarium solani f. sp. piperis $\mathrm{Si}$-supplemented (ISi+) or nonsupplemented ( $\mathrm{ISi}-$ ). The leaves were previously dark-adapted for $30 \mathrm{~min}(n=10)$.

Kottanadan pepper cultivar indicates higher homogeneity of samples (Fig. $2 A$ ), which can be associated with higher ability to balance the photosynthetic electron transport under Fusarium infection. Furthermore, the Si increased the fluorescence yield in Bragantina pepper cultivar, evidenced by increases mainly of I and P steps of the OJIP curves (Fig. 2B), which refer to the processes of reduction of the final electron acceptors at the PSI acceptor side, such as ferredoxin (Fd) and NADP (Yusuf et al. 2010), indicating higher pool of the final electron acceptors of PSI in ISi+ plants. This reflects more efficient electron transfer to the PSI acceptor side. A positive increase in the I-P phase may indicate enhanced capacity of the final acceptor of PSI to receive electrons and form NADPH (Stirbet and Govindjee 2011). According to Gill and Tuteja (2010), the electron flow from the excited photosystem centers is directed to NADP, which is reduced to NADPH. However, it remains unclear whether the activity of the final electron acceptors of PSI (ferredoxin) increases with stress conditions or whether there is another mechanism increasing the apparent efficiency of PSI in receiving electrons from PSII, because not all of the electrons 
Table 2. JIP-test parameters and total chlorophyll index $\left(\mathrm{Chl}_{\text {total }}\right)$ of black pepper plants cultivars Kottanadan and Bragantina, healthy control plants (NISi-), inoculated plants with Fusarium solani f. sp. piperis Si-supplemented (ISi+) or nonsupplemented (ISi-). evaluated at $180 \mathrm{~d}$ after inoculation. In the line, means followed by the identical letter are not statistically different according to by Scott-Knott's test. Values are the means $\pm \mathrm{SE}, n=10 .{ }^{* *}-$ significant at $1 \%$ probability $(p<0.01) ;{ }^{*}-$ significant at $5 \%$ probability $(p<0.05) . \mathrm{F}_{0}$ - initial fluorescence; $\mathrm{F}_{\mathrm{m}}$ - maximum fluorescence; $\mathrm{F}_{\mathrm{v}} / \mathrm{F}_{\mathrm{m}}-$ maximum photochemical quantum yield of PSII; $\mathrm{V}_{\mathrm{J}}-$ relative variable Chl $a$ fluorescence at the J-step; $\mathrm{ABS} / \mathrm{RC}$ - absorption flux per reaction center of PSII; $\mathrm{DI}_{0} / \mathrm{RC}$ - dissipated energy flux per reaction center of PSII; $\varphi_{\mathrm{E} 0}-$ quantum yield for electron transport; $\varphi_{\mathrm{D} 0}-$ quantum yield (at $\mathrm{t}=0$ ) of energy dissipation; $\varphi_{\mathrm{R} 0}$ quantum yield for reduction of the end electron acceptors at the PSI acceptor side; $\psi_{\mathrm{E} 0}$ - efficiency with which a trapped exciton can move an electron into the electron transport chain; $\mathrm{PI}_{\text {total }}$ - photosynthetic performance index.

\begin{tabular}{|c|c|c|c|c|c|c|}
\hline & $\begin{array}{l}\text { Kottanadan } \\
\text { NISi- }\end{array}$ & ISi- & ISi+ & $\begin{array}{l}\text { Bragantina } \\
\text { NISi- }\end{array}$ & ISi- & ISi+ \\
\hline $\mathrm{F}_{0}$ & $772.33 \pm 9.00^{\mathrm{d}^{* *}}$ & $912.06 \pm 47.62^{\mathrm{c}^{* *}}$ & $802.70 \pm 16.87^{\mathrm{d}^{* *}}$ & $982.83 \pm 22.49^{\mathrm{b} * *}$ & $1034.42 \pm 54.16^{\mathrm{a}^{* *}}$ & $919.40 \pm 14.66^{\mathrm{c}^{* *}}$ \\
\hline $\mathrm{F}_{\mathrm{m}}$ & $2.940 .27 \pm 16.23^{\mathrm{a}^{* *}}$ & $2.914 .71 \pm 38.05^{\mathrm{a}^{* *}}$ & $2.909 .31 \pm 36.78^{\mathrm{a}^{* *}}$ & $2.647 .74 \pm 18.61^{\mathrm{b}^{* *}}$ & $2.398 .15 \pm 22.25^{\mathrm{c}^{* * *}}$ & $2.565 .27 \pm 23.62^{\mathrm{b}^{* *}}$ \\
\hline $\mathrm{F}_{\mathrm{v}} / \mathrm{F}_{\mathrm{m}}$ & $0.74 \pm 0.00^{\mathrm{a}^{* *}}$ & $0.68 \pm 0.03^{b^{* *}}$ & $0.73 \pm 0.03^{\mathrm{a}^{* *}}$ & $0.63 \pm 0.04^{b^{* *}}$ & $0.56 \pm 0.03^{\mathrm{c}^{* *}}$ & $0.65 \pm 0.02^{\mathrm{b}^{* *}}$ \\
\hline $\mathrm{V}_{\mathrm{J}}$ & $0.58 \pm 0.56^{\mathrm{a}^{* *}}$ & $0.59 \pm 0.00^{\mathrm{a}^{* *}}$ & $0.57 \pm 0.00^{\mathrm{a}^{* *}}$ & $0.54 \pm 0.03^{b^{* *}}$ & $0.57 \pm 0.00^{\mathrm{a}^{* *}}$ & $0.53 \pm 0.00^{\mathrm{b}^{* *}}$ \\
\hline $\mathrm{ABS} / \mathrm{RC}$ & $3.30 \pm 0.09^{c^{*}}$ & $3.59 \pm 0.53^{\mathrm{c}^{*}}$ & $3.08 \pm 0.31^{\mathrm{c}^{*}}$ & $5.70 \pm 1.45^{\mathrm{a}^{*}}$ & $4.89 \pm 0.42^{\mathrm{b}^{*}}$ & $5.08 \pm 0.06^{\mathrm{a}^{*}}$ \\
\hline $\mathrm{DI}_{0} / \mathrm{RC}$ & $1.10 \pm 0.04^{b^{* *}}$ & $1.42 \pm 0.05^{\mathrm{b}^{* *}}$ & $1.04 \pm 0.04^{\mathrm{b}^{* *}}$ & $3.35 \pm 1.34^{\mathrm{a}^{* *}}$ & $2.48 \pm 0.21^{\mathrm{c}^{* *}}$ & $2.82 \pm 0.20^{\mathrm{b} * *}$ \\
\hline$\varphi_{\mathrm{E} 0}$ & $0.30 \pm 0.07^{\mathrm{a}^{* *}}$ & $0.28 \pm 0.00^{\mathrm{a}^{* *}}$ & $0.30 \pm 0.00^{\mathrm{a}^{* *}}$ & $0.27 \pm 0.05^{\mathrm{a}^{* *}}$ & $0.25 \pm 0.00^{\mathrm{b} * *}$ & $0.27 \pm 0.01^{\mathrm{a}^{* *}}$ \\
\hline$\varphi_{\mathrm{D} 0}$ & $0.32 \pm 0.05^{\mathrm{c}^{*}}$ & $0.36 \pm 0.02^{\mathrm{b}^{*}}$ & $0.33 \pm 0.01^{\mathrm{c}^{*}}$ & $0.44 \pm 0.06^{\mathrm{a}^{*}}$ & $0.44 \pm 0.02^{\mathrm{a}^{*}}$ & $0.43 \pm 0.00^{\mathrm{a}^{*}}$ \\
\hline$\varphi_{\mathrm{R} 0}$ & $0.12 \pm 0.00^{\mathrm{a}^{* *}}$ & $0.09 \pm 0.00^{\mathrm{b} * *}$ & $0.13 \pm 0.01^{\mathrm{a}^{* *}}$ & $0.09 \pm 0.06^{b^{* *}}$ & $0.09 \pm 0.00^{\mathrm{b} * *}$ & $0.09 \pm 0.00^{\mathrm{b}^{* *}}$ \\
\hline$\psi_{\mathrm{E} 0}$ & $0.43 \pm 0.01^{\mathrm{b}^{* *}}$ & $0.43 \pm 0.03^{\mathrm{b}^{* *}}$ & $0.44 \pm 0.02^{\mathrm{b}^{* *}}$ & $0.43 \pm 0.04^{\mathrm{b}^{* *}}$ & $0.43 \pm 0.04^{b^{* *}}$ & $0.46 \pm 0.02^{\mathrm{a}^{* *}}$ \\
\hline $\mathrm{PI}_{\text {total }}$ & $2.36 \pm 0.11^{\mathrm{b}^{* *}}$ & $1.79 \pm 0.18^{\mathrm{c} * *}$ & $3.58 \pm 0.11^{\mathrm{a}^{* *}}$ & $1.90 \pm 0.64^{\mathrm{c}^{* *}}$ & $1.41 \pm 0.23^{\mathrm{c}^{* *}}$ & $2.13 \pm 0.30^{\mathrm{b} * *}$ \\
\hline $\mathrm{Chl}_{\text {total }}$ & $55.47 \pm 0.48^{\mathrm{b}^{* *}}$ & $51.74 \pm 0.68^{b * *}$ & $67.37 \pm 0.57^{\mathrm{a}^{* *}}$ & $46.65 \pm 0.60^{\mathrm{c}^{* *}}$ & $40.97 \pm 0.59^{\mathrm{d}^{* *}}$ & $46.44 \pm 0.23^{\mathrm{c}^{* *}}$ \\
\hline
\end{tabular}

that reach ferredoxin result in the formation of NADPH (Shikanai 2007). The electrons originating from the reduced ferredoxin connected with PSI can interact with ferredoxindependent enzymes to assimilate inorganic nitrogen, sulfur to fix molecular nitrogen and regulate the $\mathrm{CO}_{2}$-assimilation cycle, lowering the electron flux toward production of NADPH (Fukuyama 2004). Also, considering the cyclic flow of electrons, which depends on the electron transfer reactions of PSI, the electrons are recycled from ferredoxin to the plastoquinone pool, which results in ATP synthesis (Shikanai 2007). Thus, it can be assumed that the enhanced I-P phase in Bragantina cultivar in ISi+ and NISi- reflects the increased electron flux toward the cyclic flow in order to improve metabolic energy (ATP) in plants infected by Fusarium. Similar results were observed by Oukarroum et al. (2009), Gomes et al. (2012) and Guha et al. (2013).

In this study, the increase of $\mathrm{F}_{0}$ observed in both pepper cultivars inoculated without $\mathrm{Si}$ (ISi-) is attributed by Schreiber and Armond (1978) as being a perturbation of thylakoid membranes leading to the separation of the light-harvesting complex associated with the PSII core complex (LHCII) and a block of the PSII reaction center. Other authors further attribute the increase of inactive CR number or the inactivation of OEC as cause of increased $\mathrm{F}_{0}$ values (Kalaji et al. 2011). This result is based on the higher $\mathrm{ABS} / \mathrm{RC}, \mathrm{DI}_{0} / \mathrm{RC}$, and $\varphi_{\mathrm{D} 0}$ values reported for the Bragantina cultivar, independently of Si-supplementation (Table 2). Also, increased $F_{m}$ values were observed for Bragantina plants in ISi+, which was similar to those values described for the healthy control plants (NISi-) (Table 2), indicating increases the efficiency of light use by Si-supplementation as previously reported by Nwugo and Huerta (2008). Furthermore, a sharp decrease of $F_{m}$ values occurred in ISi-, indicating functional alterations on photosystems followed by drastic reductions of $\mathrm{Chl}_{\text {total }}$, which ultimately affected the efficiency of excitation energy from the light-harvesting capacity (Rios et al. 2017).

Although with lower extension for Bragantina pepper cultivar, the increase of $\mathrm{F}_{\mathrm{v}} / \mathrm{F}_{\mathrm{m}}$ in ISi+ and healthy control plants (NISi-), compared with ISi- plants, suggests that photosynthetic electron transport was not fully blocked during the $F$. solani infection process and that Si presence increases the photosynthetic efficiency. According to Oukarroum et al. (2015) and Khan et al. (2017), Si has a role in enhancing detoxification of reactive oxygen species under stress conditions and, consequently, $\mathrm{Chl}_{\text {total }}$ increases, which leads to higher $\mathrm{F}_{\mathrm{v}} / \mathrm{F}_{\mathrm{m}}$ (Table 2). Tatagiba et al. (2016) reported that $\mathrm{Si}$ maintain the photochemical performance of rice plants infected by Monographella albescens. According to Maxwell and Johnson (2000), increased $F_{v} / F_{m}$ under Si-supplementation reduced the occurrence of photoinhibition, where $\mathrm{F}_{\mathrm{v}} / \mathrm{F}_{\mathrm{m}}$ has a significant positive correlation with $P_{\mathrm{N}}$ and Chl values, as observed in our results (Table 1). The $\mathrm{F}_{\mathrm{v}} / \mathrm{F}_{\mathrm{m}}$ ratio indicates the potential photochemical efficiency of PSII and is calculated as the proportional photosynthetic rate in intact leaves (Björkman and Demmig 1987).

Furthermore, a marked increase of $\mathrm{PI}_{\text {total }}$ values occurred in Kottanadan and Bragantina pepper cultivars when Sisupplemented, confirming the role of $\mathrm{Si}$ in improving the electron transport chain until reduction of the final acceptors of PSI. This positive role of Si has been reported in other studies (Chen et al. 2011, Habibi and Hajiboland 2013, Aucique-Pérez et al. 2014). $\mathrm{PI}_{\text {total }}$ represents the energy flow efficiency of the photosynthetic transport 

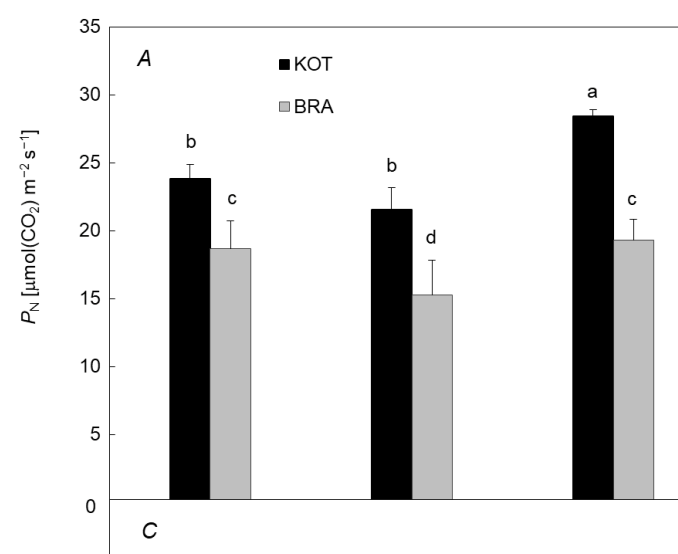

B

350
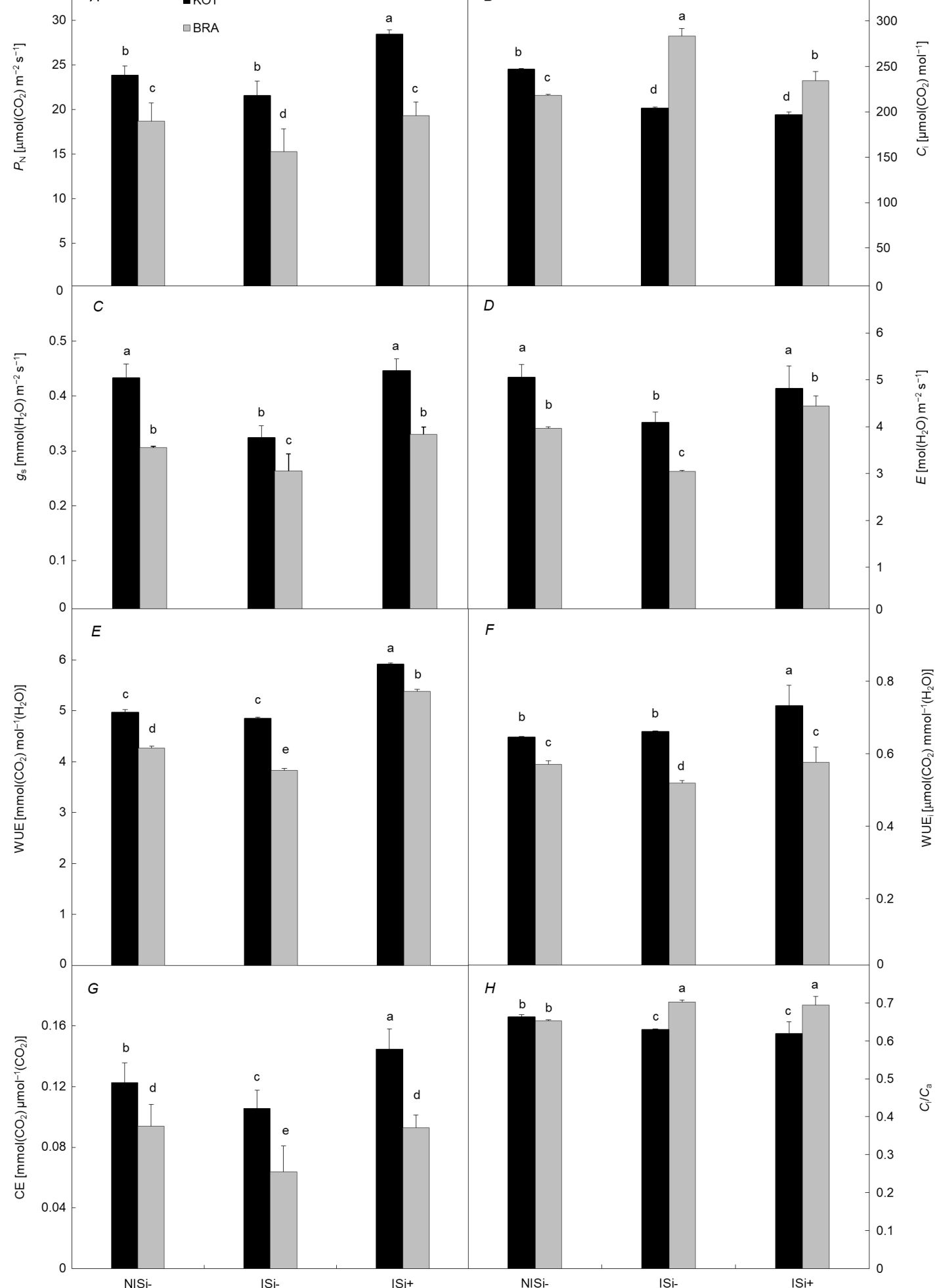

ISi+

TREATMENT

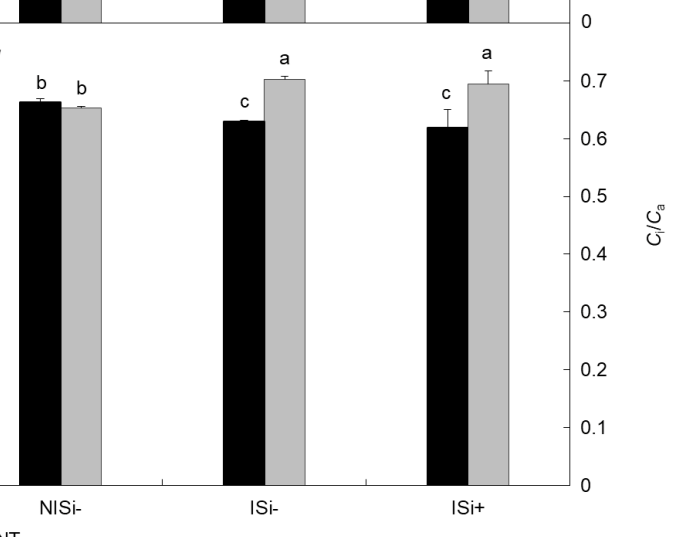

Fig. 3. Net photosynthetic rate $\left(P_{\mathrm{N}}\right)(A)$, internal $\mathrm{CO}_{2}$ concentration $\left(C_{\mathrm{i}}\right)(B)$, stomatal conductance $\left(g_{\mathrm{s}}\right)(C)$, transpiration rate $(E)(D)$, water-use efficiency (WUE) $(E)$, intrinsic water-use efficiency $\left(\mathrm{WUE}_{\mathrm{i}}\right)(F)$, carboxylation efficiency $(\mathrm{CE})(G)$, and intra/extracellular $\mathrm{CO}_{2}$ concentrations $\left(C_{\mathrm{i}} / C_{\mathrm{a}}\right)(H)$ of two black pepper cultivars (KOT - Kottanadan. BRA - Bragantina), healthy control plants (NISi-), supplemented and nonsupplemented with silicon (ISi+ and ISi-, respectively). All plants were inoculated with Fusarium solani $\mathrm{f}$. sp. piperis except the control. Values are the means $\pm \mathrm{SE}, n=10$. Columns followed by the identical letter are not statistically different according to the Scott-Knott's test at $5 \%$ probability $(p<0.05)$. 
chain (Yusuf et al. 2010) and is closely related to the overall growth and survival of plants under stress conditions and has been described as a very sensitive parameter for the JIP-test.

Finally, we observed that $\varphi_{\mathrm{E} 0}$ and $\psi_{\mathrm{E} 0}$ decreased in Bragantina plants infected by Fusarium (Table 2). $\varphi_{\mathrm{E} 0}$ and $\psi_{\mathrm{E} 0}$ express the quantum yield of electron transport and the probability that a trapped exciton moves an electron into the electron transport chain beyond $\mathrm{Q}_{\mathrm{A}}$ (or yield of $\mathrm{Q}_{\mathrm{A}}^{-}$reoxidation), respectively. These results suggest fast accumulation of $\mathrm{Q}_{\mathrm{A}^{-}}$in PSII reaction centers, showing a rise of $\mathrm{V}_{\mathrm{J}}$ due to the blockage of PSII electron flow beyond $\mathrm{Q}_{\mathrm{A}}^{-}$, inactivating PSII RCs (Chen et al. 2015). Similar results were found by Mehta et al. (2010) and Kalaji et al. (2018). In contrast, increases in $\varphi_{\mathrm{R} 0}$ were observed for Kottanadan plants in ISi+ and NISi-, indicating efficient electron transfer towards the end electron acceptors of PSI (Kalaji et al. 2018).

To better explore the role of $\mathrm{Si}$ improving the resistance in pepper cultivars against infection by $F$. solani, a detailed gas-exchange analysis was carried out (Fig. 3). Regardless of cultivar, Si-supplementation improved the gas-exchange performance of plants inoculated with $F$. solani. Resende et al. (2012) reported that fungal infections negatively affect $P_{\mathrm{N}}$ due to the physical limitations of $\mathrm{CO}_{2}$ influx into leaves. In the Piper nigrum $\times$ Fusarium solani pathosystem, the presence of enzymes and toxins produced by the fungus can prevent the functioning of xylem vessels to transport water and photoassimilates (Leslie and Summerell 2006), triggering the closure of the stomata. The $\mathrm{Si}$ application $(\mathrm{ISi}+)$ resulted in significant $(p<0.05)$ increases in $P_{\mathrm{N}}$ and $g_{\mathrm{s}}$, which were associated with decreases in $C_{\mathrm{i}}$ in the Bragantina cultivar (Fig. $3 A-C$ ). These results suggest that the higher influx of $\mathrm{CO}_{2}$ into leaves caused by stomatal opening was a prominent factor in the increase of $P_{\mathrm{N}}$ in both pepper cultivars treated with $\mathrm{Si}$. In contrast, in $\mathrm{Si}-$ plants ( $\mathrm{ISi}-$ ), the lower $P_{\mathrm{N}}, g_{\mathrm{s}}$, and $E$ values (Fig. $3 A, C, D$ ), associated with higher $C_{\mathrm{i}}$ values (Fig. $3 B$ ), suggest that photosynthesis of the Bragantina cultivar was limited by nonstomatal factors. Additional support for this conclusion comes from the nonsignificant correlation between $P_{\mathrm{N}}$ and $g_{\mathrm{s}}(r=0.83)$, the negative correlation between $P_{\mathrm{N}}$ and $C_{\mathrm{i}}(r=0.49, p<0.01)$, and the positive correlation between blast severity and $C_{\mathrm{i}}$ $(r=0.47, p<0.01)$. Similar results have been found in other pathosystems and these results have usually been interpreted as an indication of biochemical, rather than diffusive, limitations of photosynthesis (Pinkard and Mohammed 2006, Dallagnol et al. 2011).

According to Alves et al. (2011), reductions of $P_{\mathrm{N}}$ values in infected plants are unlikely to be only associated with lower $\mathrm{CO}_{2}$ entry into the leaves, but also with some biochemical limitation in $\mathrm{CO}_{2}$ fixation within the chloroplasts. Frequently, alterations in leaf photochemistry and carbon metabolism are related to lower Rubisco activity and changes in the capacity for ribulose-1,5-bisphosphate regeneration (Hiscox and Israelstam 1979). Reductions of $E$ in soybean leaves infected by Phakopsora pachyrhizi can be associated with reduced $g_{s}$, and therefore associated with stomatal closure (Rios et al. 2017). Reductions of $E$ maintain a favorable water status in the infected leaves (Resende et al. 2012). Reductions in the values of both $E$ and $g_{\text {s }}$ have been also reported by Alves et al. (2011). According to Debona et al. (2014), decreases in $E$ were mainly governed by $g_{s}$, which was further corroborated by the positive and significant correlation between $E$ and $g_{s}$, supporting our results (Table 1).

In despite of the reductions in $g_{\mathrm{s}}$, fungus-induced changes in photosynthesis were largely related to the light capture capacity and the reduced capacity of the mesophyll to fix $\mathrm{CO}_{2}$ (Dallagnol et al. 2011). Thus, the decrease of photosynthetic productivity in response to the disease resulted in a lower amount of healthy leaf area, mainly for Bragantina cultivar in ISi-. Furthermore, the reduction of photosynthetic activity in diseased leaves was related to decomposition of Chl (Table 2), as indicated by continuous yellowing of photosynthetic foliar tissues. Similar results have been found in other pathosystems (Oryza sativa $\times$ Bipolaris oryzae; Sorghum $\times$ Colletotrichum sublineolum; Triticum aestivum $\times$ Pyricularia oryzae) and were interpreted as an indication of biochemical limitations of photosynthesis (Pinkard and Mohammed 2006, Dallagnol et al. 2011, Resende et al. 2012, Aucique-Pérez et al. 2017, 2019). Finally, the results of CE (Fig. 3G) indicate that the decreased $P_{\mathrm{N}}$ values were mainly associated with lower apparent Rubisco activity (Debona et al. 2014) supporting the biochemical limitations of photosynthesis as previously described above. All leaf gas-exchange variables were less affected in those more resistant pepper cultivars infected by F. solani (Fig. 3).

In conclusion, the chlorophyll content, chlorophyll $a$ fluorescence, and leaf gas-exchange parameters were less affected in Si-supplemented plants (ISi+) as well as healthy control plants (NISi-). Although the two pepper cultivars had shown high disease severity compared with healthy control plants (NISi-), the analysis of the OJIP phases showed that the plants inoculated with $F$. solani remained photosynthetically active after the infection. Damages on the photosynthesis and chlorophyll content were significantly minimized in both cultivars with Sisupplementation. Finally, the results of this study provide further evidence that black pepper's photosynthetic machinery can be greatly protected in susceptible plants supplied with $\mathrm{Si}$ before infection by $F$. solani. This protection is apparently associated with the preservation of photosynthetic performance.

\section{References}

Ajigboye O.O., Bousquet L., Murchie E.H., Ray R.: Chlorophyll fluorescence parameters allow the rapid detection and differentiation of plant responses in three different wheat pathosystems. - Funct. Plant Biol. 43: 356-369, 2016.

Alves A.A., Guimarães L.M.S., Chaves A.R.M. et al.: Leaf gas exchange and chlorophyll $a$ fluorescence of Eucalyptus urophylla in response to Puccinia psidii infection. - Acta Physiol. Plant. 33: 1831-1839, 2011.

Aucique-Pérez C.E., Menezes Silva P.E., Moreira W.R. et al.: Photosynthesis impairments and excitation energy dissipation on wheat plants supplied with silicon and infected with Pyricularia oryzae. - Plant Physiol. Bioch. 121: 196-205, 
2017.

Aucique-Pérez C.E., Resende R., Cruz Neto L.B. et al.: Picolinic acid spray stimulates the antioxidative metabolism and minimizes impairments on photosynthesis on wheat leaves infected by Pyricularia oryzae. - Physiol. Plantarum 167: 628-644, 2019.

Aucique-Pérez C.E., Rodrigues F.A., Moreira W.R., DaMatta F.M.: Leaf gas exchange and chlorophyll $a$ fluorescence in wheat plants supplied with silicon and infected with Pyricularia oryzae. - Phytopathology 104: 143-149, 2014.

Bélanger R.R., Benhamou N., Menzies J.G.: Cytological evidence of an active role of silicon in wheat resistance to powdery mildew (Blumeria graminis f. sp. tritici). - Phytophatology 93: 402-412, 2003

Berger S., Sinha A.K., Roitsch T.: Plant physiology meets phytopathology: Plant primary metabolism and plant pathogen interactions. - J. Exp. Bot. 58: 4019-4026, 2007.

Berhow M.A., Vaughn S.F.: Higher plant flavonoids: biosynthesis and chemical ecology. - In: Inderjit, Dakshini K.M.M., Foy C.L. (ed.): Principles and Practices in Plant Ecology. Pp. 423-438. CRC Press, Boca Raton 1999.

Björkman O., Demmig B.: Photon yield of $\mathrm{O}_{2}$ evolution and chlorophyll fluorescence characteristics at $77 \mathrm{~K}$ among vascular plants of diverse origins. - Planta 170: 489-504, 1987.

Campbell C.L., Madden L.V.: Introduction to Plant Disease Epidemiology. Pp. 532. John Wiley \& Sons, New York 1990.

Chen S., Kang Y., Zhang M. et al.: Differential sensitivity to the potential bioherbicide tenuazonic acid probed by the JIP-test based on fast chlorophyll fluorescence kinetics. - Environ. Exp. Bot. 112: 1-15, 2015.

Chen W., Yao X., Cai K, Chen J.: Silicon alleviates drought stress of rice plants by improving plant water status, photosynthesis and mineral nutrient absorption. - Biol. Trace Elem. Res. 142: 67-76, 2011

Chérif M., Asselin A., Bélanger R.R.: Defense responses induced by soluble silicon in cucumber roots infected by Pythium spp.Phytopathology 84: 236-242, 1994.

Chérif M., Benhamou N., Bélanger R.R.: Ultrastructural and cytochemical studies of fungal development and host reactions in cucumber plants infected by Pythium ultimum. - Physiol. Mol. Plant P. 39: 353-375, 1991.

Cruz C.D.: Genes Software - extended and integrated with the R, Matlab and Selegen. - Acta Sci.-Agron. 38: 547-552, 2016.

Dallagnol L.J., Rodrigues F.A., Martins S.C.V. et al.: Alterations on rice leaf physiology during infection by Bipolaris oryzae.Australas Plant Path. 40: 360-365, 2011.

Dallagnol L.J., Rodrigues F.A., Mielli M.V.B.: Silicon improves the emergence and sanity of rice seedlings obtained from seeds infected with Bipolaris oryzae. - Trop. Plant Pathol. 38: 478-484, 2013

Datnoff L.E., Rodrigues F.A., Seebold K.W.: Silicon and plant disease. - In: Datnoff L.E., Elmer W.H., Huber D.M. (ed.): Mineral Nutrition and Plant Disease. Pp. 233-246. The American Phytopathological Society Press, St. Paul 2007.

Debona D., Rodrigues F.A., Datnoff L.E.: Silicon's role in abiotic and biotic plant stresses. - Annu. Rev. Phytopathol. 55: 85$107,2017$.

Debona D., Rodrigues F.A., Rios J.A. et al.: Limitations to photosynthesis in leaves of wheat plants infected by Pyricularia oryzae. - Phytopathology 104: 34-39, 2014.

Domiciano G.P., Cacique I.S., Freitas C.C. et al.: Alterations in gas exchange and oxidative metabolism in rice leaves infected by Pyricularia oryzae are attenuated by silicon. Phytopathology 105: 738-747, 2015.

Fauteux F., Rémus-Borel W., Menzies J.G., Bélanger R.R.:
Silicon and plant disease resistance against pathogenic fungi. FEMS Microbiol. Lett. 249: 1-6, 2005.

Fawe A., Abou-Zaid M., Menzies J.G., Bélanger R.R.: Siliconmediated accumulation of flavonoid phytoalexins in cucumber. - Phytopathology 88: 396-401, 1998.

Fernandes A.A., Martinez H.E.P., Fontes P.C.R.: [Productivity, fruit quality and nutritional status of single truss long shelf life tomato, cultivated in hydroponic system, with different nutrient sources.] - Hortic. Bras. 20: 564-570, 2002. [In Portuguese]

Fortunato A.A., Rodrigues A., Nascimento K.J.T.: Physiological and biochemical aspects of the resistance of banana plants to Fusarium wilt potentiated by silicon. - Phytopathology 102: 957-966, 2012.

Fukuyama K.: Structure and function of plant-type ferredoxins. Photosynth. Res. 81: 289-301, 2004

Ghini R.: [Solarization: history, recent results and perspectives.] Summa Phytopathol. 30: 139-140, 2004. [In Portuguese]

Gill S.S., Tuteja N.: Reactive oxygen species and antioxidant machinery in abiotic stress tolerance in crop plants. - Plant Physiol. Bioch. 48: 909-930, 2010.

Gomes M.T.G., Luz A.C., Santos M.R. et al.: Drought tolerance of passion fruit plants assessed by the OJIP chlorophyll $a$ fluorescence transient. - Sci. Hortic.-Amsterdam 142: 49-56, 2012.

Guha A., Sengupta D., Reddy A.R.: Polyphasic chlorophyll $a$ fluorescence kinetics and leaf protein analyses to track dynamics of photosynthetic performance in mulberry during progressive drought. - J. Photoch. Photobio. B 119: 71-83, 2013.

Habibi G., Hajiboland R.: Alleviation of drought stress by silicon supplementation in pistachio (Pistacia vera L.) plants. - Folia Hortic. 25: 21-29, 2013.

Hiscox J.D., Israelstam G.F.: A method for the extraction of chlorophyll from leaf tissue without maceration. - Can. J. Bot. 57: 1332-1334, 1979.

Kalaji H.M., Bąba W., Gediga K. et al.: Chlorophyll fluorescence as a tool for nutrient status identification in rapeseed plants. Photosynth. Res. 136: 329-343, 2018.

Kalaji H.M., Govindjee, Bosa K. et al.: Effects of salt stress on photosystem II efficiency and $\mathrm{CO}_{2}$ assimilation of two Syrian barley landraces. - Environ. Exp. Bot. 73: 64-72, 2011.

Khan W.D., Aziz T., Hussain I. et al.: Silicon: a beneficial nutrient for maize crop to enhance photochemical efficiency of photosystem II under salt stress. - Arch. Agron. Soil. Sci. 63: 599-611, 2017.

Lemos O.F., Poltronieri M.C., Menezes I.C. et al.: [Conservation and genetic improvement of black pepper (Piper nigrum L.): in association with biotechnology techniques.] $1^{\text {st }}$ Edition. Pp. 47. Embrapa Amazônia Oriental, Belém do Pará, 2011. [In Portuguese]

Leslie J.F., Summerell B.A.: The Fusarium Laboratory Manual. Pp. 387. Blackwell Publishing, Oxford 2006.

Maxwell K., Johnson G.N.: Chlorophyll fluorescence a practical guide. - J. Exp. Bot. 51: 659-668, 2000.

Meharg C., Meharg A.A.: Silicon, the silver bullet for mitigating biotic and abiotic stress, and improving grain quality, in rice? Environ. Exp. Bot. 120: 8-17, 2015.

Mehta P., Jajoo A., Mathur S., Bharti S.: Chlorophyll a fluorescence study revealing effects of high salt stress on Photosystem II in wheat leaves. - Plant Physiol. Bioch. 48: 16-20, 2010.

Nwugo C.C., Huerta A.J.: Silicon-induced cadmium resistance in rice (Oryza sativa). - J. Plant Nutr. Soil. Sc. 171: 841-848, 2008

Oukarroum A., Bussotti F., Goltsev V., Kalaji H.M.: Corre- 
lation between reactive oxygen species production and photochemistry of photosystems I and II in Lemna gibba L. plants under salt stress. - Environ. Exp. Bot. 109: 80-88, 2015.

Oukarroum A., Schansker G., Strasser R.J.: Drought stress effects on photosystem I content and photosystem II thermotolerance analyzed using Chl $a$ fluorescence kinetics in barley varieties differing in their drought tolerance. - Physiol. Plantarum 137: 188-199, 2009.

Pinkard E.A., Mohammed C.L.: Photosynthesis of Eucalyptus globulus with Mycosphaerella leaf disease. - New Phytol. 170: 119-127, 2006.

Rasoolizadeh A., Labbé C., Sonah H. et al.: Silicon protects soybean plants against Phytophthora sojae by interfering with effector-receptor expression. - BMC Plant Biol. 18: 97, 2018.

Ratnayake R.M.R.N.K., Daundasekera W.A.M., Ariyarathne H.M., Ganehenege M.Y.U.: Soil application of potassium silicate reduces the intensity of downy mildew in bitter gourd (Momordica charantia L.) leaves. - Ceylon J. Sci. 45: 23-31, 2016.

Resende R.S., Rodrigues F.A., Cavatte P.C. et al.: Leaf gas exchange and oxidative stress in sorghum plants supplied with silicon and infected with Colletotrichum sublineolum. Phytopathology 102: 892-898, 2012.

Resende R.S., Rodrigues F.A., Costa R.V., Silva D.D.: Silicon and fungicide effects on anthracnose in moderately resistant and susceptible sorghum lines. - J. Phytopathol. 161: 11-17, 2013.

Rios J.A., Rodrigues F.A., Debona D., Silva L.C.: Photosynthetic gas exchange in leaves of wheat plants supplied with silicon and infected with Pyricularia oryzae. - Acta Physiol. Plant. 36: 371-379, 2014.

Rios V., Rios J., Aucique-Pérez C.E. et al.: Leaf gas exchange and chlorophyll $a$ fluorescence in soybean leaves infected by Phakopsora pachyrhizi. - J. Phytopathol. 166: 75-85, 2017.

Rodrigues F.A., Dallagnol L.J., Duarte H.S.S., Datnoff L.E.: Silicon control of foliar diseases in monocots and dicots. - In: Rodrigues F.A, Datnoff L.E. (ed.): Silicon and Plant Diseases. Pp. 67-108. Springer, Cham 2015.

Rodrigues F.A., Jurick W.M., Datnoff L.E. et al.: Silicon influences cytological and molecular events incompatible and incompatible rice-Magnaporthe grisea interactions. Physiol. Mol. Plant P. 66: 144-159, 2005.

Schreiber U.: Pulse-Amplitude-Modulation (PAM) fluorometry and saturation pulse method: An overview. - In: Papageorgiou G.C., Govindjee (ed.): Chlorophyll Fluorescence: A Signature of Photosynthesis. Pp. 279-319. Springer Verlag, Dordrecht 2004.

Schreiber U., Armond P.A.: Heat induced changes of chlorophyll fluorescence in isolated chloroplasts and related heat damage at the pigment level. - BBA-Bioenergetics 502: 138-151, 1978.

Shikanai T.: Cyclic electron transport around photosystem I: genetic approaches. - Annu. Rev. Plant. Biol. 58: 199-217, 2007.

Spósito M.B., Amorim L. Belasque Júnior J. et al.: [Elaboration and validation of diagrammatic scale to evaluate black spot severity in citrus fruits.] - Fitopatol. Bras. 29: 81-85, 2004. [In Portuguese]

Stirbet A., Govindjee: On the relation between the Kautsky effect (chlorophyll $a$ fluorescence induction) and Photosystem II: Basics and applications of the OJIP fluorescence transient. J. Photoch. Photobio. B 104: 236-257, 2011.

Strasser B.J., Strasser R.J.: Measuring fast fluorescence transients to address environmental questions: The JIP test. - In: Mathis P. (ed.): Photosynthesis: From Light to Biosphere. Vol. 5. Pp. 977-980. Kluwer Academic Publishers, Dordrecht 1995.

Syvertsen J.P., Bausher M.G. Albrigo L.G.: Water relations and related leaf characteristics of healthy and blight affected citrus trees. - J. Am. Soc. Hortic. Sci. 105: 431-434, 1980.

Tamai K., Ma J.F.: Reexamination of silicon effects on rice growth and production under field conditions using a low silicon mutant. - Plant Soil 307: 21-27, 2008.

Tatagiba S.D., DaMatta F.M., Rodrigues F.A.: Silicon partially preserves the photosynthetic performance of rice plants infected by Monographella albescens. - Ann. Appl. Biol. 168: 111-121, 2016.

Tremacoldi C.R.: [Main Fungal Diseases of Black Pepper in the State of Pará and Control Recommendations.] $1^{\text {st }}$ Edition. Pp. 25. Embrapa Amazônia Oriental, Belém do Pará 2010. [In Portuguese]

Wheeler T., Rush C.M.: Soilborne diseases. - In: Maloy O.C., Murray T.D. (ed.): Encyclopedia of Plant Pathology. Pp. 935947. John Wiley \& Sons, New York 2001.

Yusuf M.A., Kumar D., Rajwanshi R. et al.: Overexpression of ( $\alpha$-tocopherol methyl transferase gene in transgenic Brassica juncea plants alleviates abiotic stress: physiological and chlorophyll a fluorescence measurement. - BBABioenergetics 1797: 1428-1438, 2010.

(C) The authors. This is an open access article distributed under the terms of the Creative Commons BY-NC-ND Licence. 